\title{
Treatment of Wastewater from Petroleum Industry: Current Practices and Perspectives
}

\author{
Sunita Varjani ${ }^{* *}$, Rutu Joshi², Vijay Kumar Srivastava ${ }^{3}$, Huu Hao Ngo $^{4}$, Wenshan Guo ${ }^{4}$ \\ ${ }^{1}$ Gujarat Pollution Control Board, Gandhinagar - 382010, Gujarat, India \\ ${ }^{2}$ School of Biological Sciences and Biotechnology, Indian Institute of Advanced Research, Gandhinagar - 382007, \\ Gujarat, India \\ ${ }^{3}$ Sankalchand Patel University, Sankalchand Patel Sahakar, Visnagar-384315, Gujarat, India \\ ${ }^{4}$ Centre for Technology in Water and Wastewater, School of Civil and Environmental Engineering, University of \\ Technology Sydney, Sydney, NSW - 2007, Australia \\ *Corresponding author: drsvs18@gmail.com
}

\begin{abstract}
Petroleum industry is one of the fastest growing industry and it significantly contributes to economic growth in developing countries like India. The wastewater from a petroleum industry consist a wide variety of pollutants like petroleum hydrocarbons, mercaptans, oil and grease, phenol, ammonia, sulphide and other organic compounds etc. All these compounds are present as very complex form in discharged water of petroleum industry, which are harmful for environment directly or indirectly. Some of the techniques used to treat oily waste/wastewater are membrane technology, photocatalytic degradation, advanced oxidation process, electrochemical catalysis, etc. In this review paper we aim to discuss past and present scenario of using various treatment technologies for treatment of petroleum industry waste/wastewater. The treatment of petroleum industry wastewater involves physical, chemical and biological processes. This review also provides scientific literature on knowledge gaps and future research directions to evaluate the effect(s) of various treatment technologies available.
\end{abstract}

Key words: Petroleum hydrocarbons; Membrane technology; Photocatalytic degradation; Waste biorefinery; Resource recovery 


\section{1) Introduction}

30

31

32

33

Water is necessary for life on earth as it is a basic need of all organisms. Rapid industrialization and economic development have led to exponential growth in population and urbanization (Zafra et al. 2015; Chen 2018). The world is witnessing an increase in urbanization and industrialization due to the consumerist approach ( $\mathrm{Li}$ and $\mathrm{Yu}$ 2011; Zhang et al. 2015). The domestic and industrial sectors continuously generate large amount of waste/wastewater at an alarming rate and usually dispose the waste without proper management and treatment (Varjani et al. 2019). Petroleum industries and refineries are important from economic growth point of view ( $\mathrm{Li}$ and $\mathrm{Yu}$ 2011; Li et al. 2014; Abdulredha et al. 2018). Petroleum refineries and petrochemical plants are facing problem of disposing the waste/wastewater generated. Wastewater released by petroleum industries contains different type of organic and inorganic pollutants such as BTEX, sulphides, hydrocarbons, phenol, heavy metals etc (He and Jiang 2008; Usman et al. 2012; Varjani 2017a; Raza et al. 2018). Large quantities of toxic substances are released by activities of petroleum industry such as production process of oil, transportation, oil refinery, petrochemical product, storage and distribution etc. These are harmful for environment and human health (Perera et al. 2012; Viggi et al. 2015; Raza et al. 2018).

The treatment of oily wastewater generated from petroleum industry involves different processes such as (1) physical, (b) chemical and (c) biological processes Various processes available for treatment of petroleum hydrocarbons polluted water ranges from applied methods to emerging methods (Usman et al. 2012; Li et al. 2014; Viggi et al. 2015; Varjani 2017b). Characteristics of oily wastewater and effect of petroleum hydrocarbons on environment and human health have been emphasized in this paper. Sections of this paper also discusses about the current treatment process used in petroleum industry and treatment methods used for treating oily wastewater. The current review focuses to generate critical review about the different practices used for wastewater treatment in petroleum industries. This review also focusses on information pertaining to the knowledge gaps and future research directions in this field.

\section{2.) Characteristics of oily wastewater}

Petroleum means "rock oil" and this word is derived from a Latin word "petra" and Greek word "oleum" (Jafarinejad 2016). Petroleum industry generates large amount of oily waste either solid or liquid due to upstream and 
downstream operations (Varjani and Upasani 2017). Upstream process includes extracting, transporting and storing crude oil and downstream process includes refining of crude oil (Al-Futaisi et al. 2007; Hu et al. 2013; Thakur et al. 2018). Depending on a ratio of water and solids waste is categorized into simple wastewater crude oil or sludge. The $\mathrm{pH}$ value of oily sludge is usually ranging from 6.5 to 7.5 , but it varies depending on sources of crude oil, processing method, reagents used etc. (Hu et al. 2013; Jasmine and Mukherji 2015). Wastewater from petroleum industry contain oil impurities, high level of BOD and COD, high total solids, hydrocarbons and other waste. This waste includes oily sludge, waste catalyst, heavy metals, volatile organic compounds, oil \& grease content, high total dissolved salts, ammonia, nitrates, sulfides, etc. (Jasmine and Mukherji 2015). Oily wastewater contains mainly four major types of petroleum hydrocarbons such as aliphatic, aromatic, asphaltenes and compounds containing oxygen, nitrogen and sulfur. It consists organo-metallic complexes with cadmium, lead, nickel and vanadium (Honse et al. 2012; Varjani and Upasani 2017; Thakur et al. 2018). Table 1 summarizes the characteristics of oily wastewater/effluents and standards for their discharge in environment. These pollutants typically disperse, emulsify or dissolve within the oily wastewater. In general aromatic and aliphatic compounds counts up to $75 \%$ of petroleum hydrocarbons in oily wastewater (Ward et al. 2003; Perera et al. 2012; Jasmine and Mukherji 2015; Varjani et al. 2018).

\section{3) Effect on environment/ human health}

3

4

Petroleum industry discharge huge amount of pollutants in environment. Wastewater released by the petroleum industries contain large quantities of hydrocarbons, heavy metals, phenols and other toxic chemicals (Perera et al. 2012; Jasmine and Mukherji 2015; Thakur et al. 2018; Varjani et al. 2018). Different activities of petroleum industry such as transportation, storage, drilling etc. take part in soil contamination by oil. Depending on type of soil lighter oil can move quickly instead of heavier oil through the soil layers (Fakhru'l-Razi et al. 2009; Varjani et al. 2017). Due to ineffectiveness of treatment system, industrial wastewater become harmful to ecosystem and other life forms (Poulopoulos et al. 2005; Veyrand et al. 2013; Varjani 2017b; Al-Hawash et al. 2018). Oily wastewater can affect different components of environment such as human health, drinking water and groundwater resources, air, crop production and aquatic life etc (Zafra et al 2015; Varjani et al. 2017). Accumulation of toxic products in the water bodies leads serious consequences on the ecosystem and living organisms either long term or short term which may be chronic or acute. (Poulopoulos et al. 2005; Usman et al. 2012; Al-Hawash et al. 2018; Varjani et al. 2018). 


\section{4) Current treatment process in petroleum industry}

87

Different technologies adsorption, coagulation, anaerobic treatment, reverse osmosis, ultrafiltration, chemical destabilization, flocculation, dissolved air flotation (DAF), membrane process etc. have been used to treat wastewater from petroleum industry (Bennett and Peters 1988; Kriipsalu et al. 2003; Sonune and Ghate 2004; Usman et al. 2012; Li et al. 2014; Padaki et al. 2015). Adsorption method has many advantages rather than other technique such as cost benefit, simplicity and adaptability (Sabah et al. 2007; Ahmad et al. 2016). Depending upon concentration and source of contamination different type of treatment technique is required to reduce the toxic level of pollutants (Sonune and Ghate 2004; Hanafy and Nabih 2007; Bennett and Peters 1988; Farajnezhad and Gharbani 2012; Li et al. 2014; Padaki et al. 2015). Mainly the treatment process has been differentiated into three categories (a) primary, (b) secondary and (c) tertiary treatment (fig.1). Generally effluent of petroleum industry is passed through different stages for reducing toxicity level which is show as a schematic diagram in in fig. 2 .

\section{1) Primary treatment}

Primary treatment is usually used for physical operation in petroleum refinery wastewater treatment plant (Ahmad et al. 2016). It is important step as it allows waste for the further secondary treatment unit. Mostly gravity separation applies to classify the floating and settle down material from wastewater. The primary treatment step includes an oil/water separator which can separate oil, water and solids. Gravity separation followed by skimming is carried out for removal of oil from wastewater (Al-Shamrani et al. 2002; Hanafy and Nabih 2007). Oil-water separator such as API oil-water separator is widely used because of low cost, high effectiveness for primary treatment step. API separators work on phenomena of difference in specific gravity to allow heavy material to settle below lighter liquids. Hydrocarbons that float on the surface and the sludge settle down to the bottom (Al-Futaisi et al. 2007; Ahmad et al. 2016). API separator is not very much applicable for removal of smaller oil droplets and emulsions (Abdulredha et al. 2018). Dissolved air flotation (DAF) is a water treatment process that uses air to increase the capacity of smaller oil droplets and enhance the separation process. DAF unit typically consist chemicals to promote coagulation and increase floc size to make easy separation. In this stage the heterogeneous components of the effluent such as suspended solids colloids or dispersion, immiscible liquids are reduced significantly (Al-Shamrani et al. 2002; Hanafy and Nabih 2007). Colloids and dispersion also delay and damage equipment during proceeding stage (Renault et al. 2009). In Induced air flotation (IAF) system, air is induced by rotor disperse mechanism, the spinning rotor work as a pump and forces 
to the fluid. The advantages of the IAF process are compact size, low cost and effective removal of free oil and suspended material (Bennett and Peters 1988; Bennett and Shammas 2010).

\section{2) Secondary treatment}

The main purpose of this stage is to reduce contamination level of effluent and make it in permissible limit for discharge into water bodies. Secondary treatment consists coagulation, flocculation and further biological treatment to reduce toxicity of petroleum wastewater (Xu and Zhu 2004; Viggi et al. 2015; Changmai et al. 2017). Petroleum effluent contains large number of refractory components. Poly aluminium chloride is more effective rather than ferric chloride in coagulation process for treatment of petroleum wastewater (Farajnezhad and Gharbani. 2012; Hosny et al. 2016). Coagulation-flocculation is a process in which chemical product is added to accelerate the sedimentation in clarification tank Coagulation-flocculation consist on the addition of chemical product to accelerate the sedimentation in clarifieation tank-(Kriipsalu et al. 2003; Moulai-Mostefa and Tir, 2004, Hosny et al. 2016). The coagulants are organic or inorganic components such as aluminium hydroxide chloride, aluminium sulphate or high molecular weight cationic polymer. The aim of addition of coagulant is to remove $90 \%$ of the suspended solids from the wastewater (Lin and Wen 2003; Changmai et al. 2017). Renault et al. (2009) have reported chitosan for efficient coagulation/flocculation process to treat petroleum industry wastewater. (Renault et al. 2009). Biological treatment is the most widely used method for removal of organic compounds in the oil industry wastewater. Biological treatment is mostly classified in to two categories (a) suspended growth process and (b) attached growth process (Chavan and Mukherji 2008; Srikanth et al. 2018). Suspended growth process includes aerated lagoon, membrane bioreactor technology, sequencing batch reactor (SBR) and activated sludge treatment. In the activated sludge process the wastewater enters in to aeration tank where microorganism brought in contact with contaminated wastewater. Microorganisms use the organic material as food and decompose organic matter (Srikanth et al. 2018). N:P ratio has been reported very important parameter for treatment of oily wastewater by using oil degrading bacteria (Chavan and Mukherji 2008).

\section{3) Tertiary treatment}

Tertiary treatment process includes sand filtration, activated carbon process and chemical oxidation. It is applicable for removal of total suspended solids, dissolved and suspended matter, COD and trace organics such as PAHs (He and Jiang 2008; Li et al. 2014). After secondary treatment process, effluent contain suspended solids 
depending on operating conditions in the clarifier. Removal of metals and fine solids which could not be settle down

145 in sedimentation process can be removed by sand filtration (Zahrim and Hilal 2013; Ahmad et al. 2016). This process

146 involves passing the wastewater through a filter bed comprised of a filter media. Generally chemical oxidation is used

147 for reduction of residual COD, trace organic compounds and non-biodegradable compounds. This method uses 148 different type of oxidation reagents like hydrogen peroxide, ozone, chlorine dioxide (Usman et al. 2012; Srikanth et 149 al. 2016).

\section{5) Treatment methods for oily wastewater}

It is important to dispose of effluent in a proper manner and it should maintain a minimum concentration level of chemical(s) which is suitable for environment. Thus, innovative research is required to develop new technologies which degrade the complex molecules into simpler forms, which is reliable to maintain water quality (Sonune and Ghate 2004; Ani et al. 2018). Petroleum industries have made few effective technologies for improving treatment capacity through different methods which are mentioned below and also have also been summarized in table

\section{1) Membrane separation technology}

Membrane separation processes are dependent on difference in (a) pressure, (b) concentration of pollutants, (c) temperature and (d) electrical potential (Al-Obaidani et al. 2008; Jamaly et al. 2015; Adhama et al. 2018). Depending upon the pore size of utilized membrane process is categorized as a (a) microfiltration (MF), (b) nanofiltration (NF), (c) ultrafiltration (UF) and (d) reverse osmosis (RO), which are mostly applied to treat oily wastewater (Bruggen et al. 2003; Tomaszewska 2007; Jamaly et al. 2015). This separation method play role in physical removal of way of the trapped particle size of contaminants (Hilal et al. 2004). According to membrane pore size ultrafiltration membranes are more effective than microfiltration membranes. Nanofiltration and reverse osmosis can be also used for separating oil from water especially for high salinity water (Zhu et al. 2014; Jamaly et al. 2015). Based on the oil dispersion, oily water can be classified into three types: (a) free-floating oil, (b) unstable oil-water emulsions

171 oil can be easily removed by mechanical techniques and also unstable emulsions removed mechanically but sometimes 
172 specific chemical additives are required (Salahi et al. 2013; Abdulredha et al. 2018). Membrane separation efficiency

173 is normally identified by oil rejection coefficient (Ro) and it is defined as:

$$
\mathbf{R}_{\mathbf{0}}=\frac{\text { Oil concentration in feed-Oil concentration in permeate }}{\text { Oil concentration in feed }} \times 100
$$

Usually, an effective membrane has high rejection coefficients for total organic carbon (TOC), total surface charge (TSC) and chemical oxygen demand (COD) (Karhu et al. 2013). Another important parameter in membrane separation 179 is the permeate flux. Permeate flux is defined by:

$$
\mathbf{J}=\frac{\mathbf{V p}}{\mathbf{A t}}
$$

Where $\mathbf{J}$ is the permeate flux, $\mathbf{V p}$ is the permeate volume, $\mathbf{A}$ is the membrane effective area, and $\mathbf{t}$ is the permeation time (Rezvanpour et al. 2009). The permeate flux also depends on membrane properties such as porosity, pore size and hydrophilicity (Mohammadi et al. 2003; Changmai et al. 2017). Due to small pore size of membrane, oil rejection coefficient is higher and use of large pore size membrane leads high permeate flux (Kocherginsky et al. 2003; Colle et al. 2009; Han et al. 2017).

\section{2) Advanced oxidation process}

The main function of advanced oxidation process is to generate high reactive free radicals. Hydroxyl radicals are effective in destroying organic chemicals because they are reactive electrophiles (Oller et al. 2011; Jamaly et al. 2015). Hydroxyl radical is strong oxidant to destroy compound that cannot be oxidized by conventional oxidant. Hydroxyl radical possess faster oxidation rate as compared to $\mathrm{H}_{2} \mathrm{O}_{2}$ or $\mathrm{KMnO}_{4}$ (Gogate and Pandit 2004; Usman et al 2012; Tijani et al. 2014). Generated hydroxyl radicals can attack organic chemicals by radical addition, hydrogen abstraction and/or electron transfer (Gogate and Pandit 2004; Tijani et al. 2014). Generation of hydroxyl radical is commonly accelerated by combining $\mathrm{O}_{3}, \mathrm{H}_{2} \mathrm{O}_{2}, \mathrm{TiO}_{2}$, UV radiation, electron-beam irradiation and ultrasound (Usman et al 2012; Li et al. 2014; Varjani 2017b). 


\section{3) Electrochemical catalysis}

Electrochemical catalysis process is related to oxidation of hydroxyl radical with a highly organic matter between substitution, addition and electron transfer process (Zhang et al. 2015; Mohan et al. 2018). It leads to the degradation of pollutants, mineralization, easy to build airtight circulation with no secondary pollution (Lin et al. 2001; Dimoglo et al. 2004; Koper 2005; Bajracharya et al. 2015; Changmai et al. 2017). Electrolysis process is applied to treat oily wastewater which leads to time dependent reduction in chemical oxygen demand (COD). The process consists three steps for effective reduction of pollutants in oily wastewater and do the remediation. The first step is the direct oxidation of oil components at the electrode, by the metal oxide itself or by hydroxyl radicals available at electrode surface. The second step is indirect oxidation of oil components by intermediate oxidizing agents formed and the third step is aggregation of suspended oil droplets by electro-flotation (Santos et al. 2006; Jamaly et al. 2015). Electrochemical catalytic treatment is more effective treatment of oily wastewater (Mohan et al. 2018). Ma and Wang (2006) have performed research with pilot scale plant having double anodes and cathodes. Anode contained active metal and graphite, however cathode contained iron and a noble metal content catalyst with big surface. They have reported approximately $90 \%$ reduction of biochemical oxygen demand (BOD) and chemical oxygen demand (COD) and $99 \%$ reduction in suspended solids by using the electrochemical process.

\section{4) Photocatalytic Degradation}

Photolytic degradation is very well researched in last decade and conventionally a method for treating petroleum wastewater (Twesme et al. 2006; Do et al. 2010; Yen et al. 2011; Varjani 2017b). Photocatalysis is beneficial process used to oxidize persistent compounds which cannot be oxidized during biological treatment (Vodyanitskii et al. 2016). $\mathrm{TiO}_{2}$ and $\mathrm{ZnO}$ are commonly used photocatalysts in the treatment of petroleum industry wastewater (Santos et al. 2006; Akpan and Hameed 2009; Vodyanitskii et al. 2016). Benefits of $\mathrm{TiO}_{2} / \mathrm{UV}$ technique are low cost, faster reaction rates, no sludge production and easy operation at ambient temperature and pressure with complete mineralization of petroleum industry wastewater (Twesme et al. 2006; Akpan and Hameed 2009; Varjani 2017b). Park and Choi (2005) have reported photocatalytic hydroxylation of aromatic ring in presence of platinum loaded $\mathrm{TiO}_{2}$, where they have used water as an oxidant. Photocatalytic degradation of naphthalene present in petroleum industry waste using $\mathrm{TiO}_{2}$ in presence of inorganic anions had been reported by Lair et al. (2007).

\section{6) Knowledge gaps and Future perspectives}


Petroleum hydrocarbon pollutants are classified as priority pollutants. The pollutants which are present in petroleum industry wastewater can be effectively remediated using different technologies (Yen et al. 2011; 231 Vodyanitskii et al. 2016). Research on study of innovative technologies with minimum environmental and economical influence indicating that it is thrust areas of research (Lin et al. 2001; Santos et al. 2006; Viggi et al. 2015; Vodyanitskii et al. 2016). This review article focuses on improving different technologies used for treatment of wastewater generated by petroleum industry activities. Petroleum industry wastewater contain different toxic substances such as toluene, xylene, benzene, ethylbenzene, phenols and PAHs, etc (Hanafy and Nabih 2007; Renault et al. 2009; Varjani et al. 2017). These pollutants are very difficult to be directly removed by using single method specifically biological treatment which is considered as green approach. Hence advanced chemical or physical treatments in combination with biological treatment are required. Apart from this for biological treatment to identify the successful species which can work ex-situ and in-situ conditions is a very important task (Varjani 2017b; Chen 2018). It has been reported that integration of various processes may give better results than individual process used for treatment of oily wastewater. But knowledge of integration of technologies is still at its infancy which needs to be explored by researchers. Recent developments are mostly more expensive, require maintenance and it's a time taking process. Hence, all industries do not participate to reduce toxicity of effluent. Future technology needs easy operating systems which are suitable for small, medium and big industries.

Huge amount of solid and liquid waste is produced due to petroleum industry activities. Management and handling of waste generated is nowadays is a big issue for local authorities not only in urban areas i.e. municipalities but also other regions in any country (Santos et al. 2006; Li and Yu 2011; Tijani et al. 2014; Jamaly et al. 2015; Varjani and Sudha 2018). Due to increased urbanization and industrialization generation of wastewater, appropriate disposal, treatment and/or recycling is posing more challenges as treatment and disposal costs large amount in terms of money. However, if we consider that "waste" word is placed wrongly and if that be used as a "resource" then resource recovery from wastes is an emerging as thrust area of research and management because it offers environment and social sustainability potentials.

Many research groups are focusing their work on recovery of various resources such as energy, bio-products, nutrients (nitrogen and phosphorous), metals from wastewater generated by anthropogenic activities (Li and Yu 2011; Honse et al. 2012; Varjani and Upasani 2017; Mohan et al. 2018; Thakur et al. 2018; Varjani et al. 2019). Valuable pollutants are present in petroleum industrial wastewaters, which can be regarded as resources after recovery (Al- 
Futaisi et al. 2007; Hu et al. 2013; Jasmine and Mukherji 2015). On one side efficient resource recovery and reuse can create sustainable livelihood whereas on the other side it supports green economy by reducing waste and improve environmental health and cost of recovery. Hence, there is a need to recycle and reuse the waste produced from activities of petroleum industry in an efficient manner. Feasible techniques to produce pollution less products create a new way for environmental and economic sustainability.

To optimize the exploitation of petroleum industry waste/wastewater and by-products there is a need to develop sustainable technologies. Focus of the research shall also be thrown on biorefinery concept for development of innovative bio-based industries because waste biorefineries may open up new market opportunities for bio-based products and achieve efficient resource utilization.

\section{7) Conclusion}

Petroleum industry wastewater can be treated by various physical, chemical and biological treatment processes. There are many hazardous components present in waste/wastewater released by the activities of petroleum industry. Successful remediation strategy should be tailored considering environment and human health.

272 Bioremediation is one of the technologies which is gaining a global interest for cleanup of petroleum hydrocarbons.

273 However, integration of various processes gives better results than individual process used for waste/wastewater 274 treatment. The current practice of industrial wastewater treatment is focused to remove pollutants from wastewaters 275 to meet the discharge standards. To resolve hazards associated with petroleum components, a suitable technology that treats waste and generates value addition would be a promising option. Study regarding the recovery of value-added

277 products from waste/wastewater with special reference to different techniques, either separately or by integration,

278 tailoring distinct features of processes are thrust area of research with respect to waste characteristics for production 279 of bio-based non-toxic by-products. Waste biorefinery concept using latest developments in biotechnological and bioengineering options pertaining to recovery of resources from petroleum industry waste/wastewater shall also be 281 explored.

\section{References}


Abdulredha MM, Aslina S, Hussain, Luqman, Abdullah C (2018) Overview on petroleum emulsions, formation, influence and demulsification treatment techniques. Arabian J. Chem. (In Press; DOI: 10.1016/j.arabjc.2018.11.014)

Adhama S, Hussaina A, Matara JM, Jansona A, Sharma R (2018) Membrane applications and opportunities for water management in the oil \& gas industry. Desalination 15:2-17

Ahmad T, Ahmad K, Alam M (2016) Sustainable management of water treatment sludge through 3`R' concept. J Cleaner Prod 124:1-13

Akpan UG, Hameed BH (2009) Parameters affecting the photocatalytic degradation of dyes using TiO2-based photocatalysts: a review. J. Hazard. Mater. 170:520-529

Al-Futaisi A, Jamrah A, Yaghi B, Taha R (2007) Assessment of alternative management techniques of tank bottom petroleum sludge in Oman. J. Hazard. Mater. 141:557-564

Al-Hawash AB, Dragh MA, Li S, Alhujaily A, Abbood HA, Zhang X, Ma F (2018) Principles of microbial degradation of petroleumm hydrocarbons in the environment. Egyptian J Aquatic Res 44:71-76

Al-Obaidani S, Curcio E, Francesca M, Profio GD, Al-Hinai H, Drioli E (2008) Potential of membrane distillation in seawater desalination: thermal efficiency, sensitivity study and cost estimation. J. Membr. Sci. 323:85-98

Al-Shamrani AA, James A, Xiao H (2002) Separation of oil from water by dissolved air flotation. Colloids Surf. A: Physicochem. Eng. Asp. 209:15-26

Ani IJ, Akpan UG, Olutoye MA, Hameed BH (2018) Photocatalytic degradation of pollutants in petroleum refinery wastewater by $\mathrm{TiO}_{2}$ - and $\mathrm{ZnO}$ - based photocatalysts: Recent development. J Cleaner Prod 205:930-954

Bajracharya S, Heijne TA, Benetton DX, Vanbroekhoven K, Buisman CJN, Strik DPBTB, Pant D (2015) Carbon dioxide reduction by mixed and pure cultures in microbial electrosynthesis using an assembly of graphite felt and stainless steel as a cathode. Bioresour. Technol. 195:14-24

Bennett GF, Peters W (1988) The removal of oil from wastewater by air flotation: A review. Crit. Rev. Env. Control, 18:3: 189-253 (DOI: 10.1080/10643388809388348)

Bennett GF, Shammas NK (2010) Separation of Oil from Wastewater by Air Flotation. In: Wang L, Shammas N, Selke W, Aulenbach D. (eds.) Flotation Technology. Handbook of Environmental Engineering, vol 12. Humana Press, Totowa, NJ, pp 85-119

Bruggen BVD, Vandecasteele C, Gestel TV, Doyen W, Leysen R (2003) A review of pressure-driven membrane processes in wastewater treatment and drinking water production. Environ. Prog. 22:46-56 
Changmai M, Pasawan M, Purkait MK (2017) Treatment of oily wastewater from drilling site using electrocoagulation followed by microfiltration. Sep. Purif. Technol. 210:463-472

Chavan A, Mukherji S (2008) Treatment of hydrocarbon-rich wastewater using oil degrading bacteria and phototrophic microorganisms in rotating biological contactor: Effect of N:P ratio. J. Hazard. Mater. 154:63-72

Chen X, Chen G, Yue PL (2002) Novel electrode system for electroflotation of wastewater. Environ. Sci. Technol. $36: 778-783$

Chen Y (2018) Evaluating greenhouse gas emissions and energy recovery from municipal and industrial solid waste using waste-to-energy technology. J Clean Prod 192:262-269

Colle RD, Fortulan CA, Fontes SR (2009) Manufacture of ceramic membranes for application in demulsification process for cross-flow microfiltration. Desalination 245:527-532

Dimoglo HY, Akbulut F, Cihan, M Karpuzcu (2004) Petrochemical wastewater treatment by means of clean electrochemical technologies. Clean Techn Environ Policy 6(4): 288-295

Do SH, Kwon YJ, Kong SH (2010) Effect of metal oxides on the reactivity of persulfate/Fe (II) in the remediation of diesel-contaminated soil and sand. J. Hazard. Mater. 182:933-936

Fakhru'l-Razi A, Pendashteh A, Abdullah LC, Biak DRA, Madaeni SS, Abidin ZZ (2009) Review of technologies for oil and gas produced water treatment. J. Hazard. Mater. 170:530-551

Farajnezhad H, Gharbani P (2012) Coagulation treatment of wastewater in petroleum industry using poly aluminum chloride and ferric chloride. Int J Res. Rev. Appl. Sci. 13(1):306-310

Gogate PR, Pandit AB (2004) A review of imperative technologies for wastewater treatment I: oxidation technologies at ambient conditions. Adv. Environ. Res. 8:501-551

Han L, Tan YZ, Netke T, Fane AG, Chew JW (2017) Understanding oily wastewater treatment via membrane distillation. J Membrane Sci, 539:284-294

Hanafy M, Nabih HI (2007) Treatment of Oily Wastewater Using Dissolved Air Flotation Technique. Energy Sources, Part A: Recovery, Utilization, and Environmental Effects. 29:143-159

He Y, Jiang JW (2008) Technology review: treating oil field wastewater. Filtr. Sep. 45:14-16

Hilal N, Al-Zoubi H, Darwish NA, Mohammad AW, Arabi MA (2004) A comprehensive review of nanofiltration membranes: treatment, pretreatment, modelling, and atomic force microscopy. Desalination 170:281-308

Honse SO, Ferreira SR, Mansur CRE, Lucas EF (2012) Separation and characterization of asphaltenic sub-fractions. Quim Nova 35:1991-1994 
Hosny R, Fathy M, Ramzi M, Moghny TA, Shama SA (2016) Treatment of the oily produced water (OPW) using coagulant mixtures. Egyptian J Petroleum 25:391-396

http://cpcb.nic.in/cpcbold/Industry-Specific-Standards/NewItem_48_notification.pdf (G.S.R 186(E), dated 18 ${ }^{\text {th }}$ March, 2008) (Last accessed: 18.02.2019)

Hu G, Li J, Zeng G (2013) Recent development in the treatment of oily sludge from petroleum industry. J. Hazard. Mater. 261:470-490

Jafarinejad S (2016) Control and treatment of sulfur compounds specially sulfur oxides $\left(\mathrm{SO}_{\mathrm{x}}\right)$ emissions from the petroleum industry: a review. Chem. Int. 2(4):242-253

Jamaly S, Giwa A, Hasan SW (2015) Recent improvements in oily wastewater treatment: Progress, challenges, and future opportunities. J Environ Sci 37:15-30

Jasmine J, Mukherji S (2015) Characterization of oily sludge from a refinery and biodegradability assessment using various hydrocarbon degrading strains and reconstitute consortia. J. Environ. Manag. 149:118-125

Karhu M, Kuokkanen T, Ramo J, Mikola M, Tanskanen J (2013) Performance of a commercial industrial-scale UFbased process for treatment of oily wastewaters. J. Environ. Manag. 128:413-420

Knight RL, Robert H Kadlec, Harry M Ohlendorf (1999) The Use of Treatment Wetlands for Petroleum Industry Effluents. Environ Sci Technol 33(7): 973-980

Kocherginsky NM, Tan CL, Lu WF (2003) Demulsification of water-in-oil emulsions via filtration through a hydrophilic polymer membrane. J. Membr. Sci. 220:117-128

Koper MTM (2005) Combining experiment and theory for understanding electocatalysis. J. Electroanal. Chem. 574:375-386

Kriipsalu M, Marques M, Maastik A (2008) Characterization of oily sludge from a wastewater treatment plant flocculation-flotation unit in a petroleum refinery and its treatment implications. J. Mater. Cycles Waste Manage. 10:79-86

Lair A, Ferronato C, Chovelon JM, Herrmann JM (2007) Naphthalene degradation in water by heterogeneous photocatalysis: An investigation of the influence of inorganic anions. J. Photochem. Photobiol., 193:193-203

Li WW, Yu HQ (2011) From wastewater to bioenergy and biochemical via two-stage bioconversion processes: a future paradigm. Biotechnol Adv. 29(6):972-982

Li X, Cao X, Wu G, Temple T, Coulon F, Sui H (2014) Ozonation of diesel-fuel contaminated sand and the implications for remediation end-points. Chemosphere, 109:71-76 
Lin CK, Tsai TY, Liu JC, Chen MC (2001) Enhanced biodegradation of petrochemical wastewater using ozonation and bac advanced treatment system. Water Res 35(3):699-704

Lin ZS, Wen W (2003) Aniline degradation by electrocatalytic oxidation. Mar. Environ. Sci. 22:15-19

Ma HZ, Wang B (2006) Electrochemical pilot-scale plant for oil field produced wastewater by $\mathrm{M} / \mathrm{C} / \mathrm{Fe}$ electrodes for injection. J. Hazard. Mater. 132:237-243

Macarie H (2005) Overview of the application of anaerobic treatment to chemical and petrochemical wastewaters. Water Sci. Technol. 42(5-6): 201-214

Mohammadi T, Kazemimoghadam M, Saadabadi M (2003) Modeling of membrane fouling and flux decline in reverse osmosis during separation of oil in water emulsions. Desalination 157:369-375

Mohan SV, Sravan JS, Butti SK, Krishna KV, Modestra JA, Velvizhi G, Kumar AN, Varjani S, Pandey A (2018) Microbial Electrochemical Technology: Emerging and Sustainable Platform. In: Mohan, SV, Varjani SJ, Pandey A (eds.) Microbial Electrochemical Technology: Sustainable Platform for Fuels, Chemicals and Remediation, Elsevier, Amsterdam, Netherlands, pp 3-17

Moulai-Mostefa N, Tir M (2004) Coupling flocculation with electroflotation for waste oil/water emulsion treatment Optimization of the operating conditions. Desalination 161:115-121

Oller I, Malato S, Sánchez-Pérez JA (2011) Combination of Advanced Oxidation Processes and biological treatments for wastewater decontamination. Sci Total Environ. 409:4141-4166

Padaki M, Murali RS, Abdullah MS, Misdan N, Moslehyani A, Kassim MA, Hilal N, Ismail AF (2015) Membrane technology enhancement in oil-water separation A review. Desalination 357:197-207

Park H, Choi W (2005) Photocatalytic conversion of benzene to phenol using modified $\mathrm{TiO}_{2}$ and polyoxometalates, Catal. Today, 101:291-297

Perera FP, Tang D, Wang S, Vishnevetsky J, Zhang B, Diaz D, Camann D, Rauh V (2012) Prenatal polycyclic aromatic hydrocarbon (PAH) exposure and child behavior at age 6-7 years. Environ. Health Perspect. 120:921926

Poulopoulos SG, Voutsas EC, Grigoropoulou HP, Philippopoulos CJ (2005) Stripping as a pretreatment process of industrial oily wastewater. J. Hazard. Mater.117:135-139

Qiu YQ, Zong H, Zhang Q (2009) Treatment of stable oil/water emulsion by novel felt-metal supported PVA composite hydrophilic membrane using cross flow ultrafiltration. Trans. Nonferrous Metals Soc. China 19:773-777 
402

403

404

405

406

407

408

409

410

411

412

413

414

415

416

417

418

419

420

421

422

423

424

425

426

427

428

429

Raza W, Lee J, Raza N, Luo Y, Kim KH, Yang J (2018) Removal of phenolic compounds from industrial waste water based on membrane-based technologies. Journal of Industrial and Engineering Chemistry (In Press; DOI: https://doi.org/10.1016/j.jiec.2018.11.024)

Renault F, Sancey B, Badot PM, Crini G (2009) Chitosan for coagulation/flocculation processes-an eco-friendly approach. Eur. Polym. J. 45:1337-1348

Rezvanpour A, Roostaazad R, Hesampour M, Nyström M, Ghotbi C (2009) Effective factors in the treatment of kerosene-water emulsion by using UF membranes. J. Hazard. Mater. 161:1216-1224

Sabah E, Ḉnar M, Ḉelik MS (2007) Decolorization of vegetable oils: Adsorption mechanism of $\beta$-carotene on acidactivated sepiolite. Food Chem. 100:1661-1668

Salahi A, Noshadi I, Badrnezhad R, Kanjilal B, Mohammadi T (2013) Nano-porous membrane process for oily wastewater treatment: optimization using response surface methodology. J. Environ. Chem. Eng. 1(3):218-225

Santos FV, Azevedo EB, Sant'Anna GL, Dezotti M (2006) Photocatalysis as a tertiary treatment for petroleum refinery wastewaters. Braz. J. Chem. Eng. 23(4) 451-460

Santos MRG, Goulart MOF, Tonholo J, Zanta CLPS (2006) The application of electrochemical technology to the remediation of oily wastewater. Chemosphere 64:393-399

Sonune A, Ghate R (2004) Developments in wastewater treatment methods. Desalination 167:55-63

Srijaroonrat P, Julien E, Aurelle Y (1999) Unstable secondary oil/water emulsion treatment using ultrafiltration: fouling control by backflushing. J. Membr. Sci. 159:11-20

Srikanth S, Kumar M, Singh D, Singh MP, Das BP (2016) Electro-biocatalytic treatment of petroleum refinery wastewater using microbial fuel cell (MFC) in 37 continuous mode operation. Bioresour. Technol. 221:70-77

Srikanth S, Kumar M, Singh D, Singh MP, Puri SK, Ramakumar SSV (2018) Long-term operation of electrobiocatalytic reactor for carbon dioxide transformation into organic molecules. Bioresour. Technol. 265:66-74

Thakur C, Srivastava VC, Mall ID, Hiwarkar AD (2018) Mechanistic study and multi response optimization of the electrochemical treatment of petroleum. Clean: Soil, Air, Water 46 (3):1700624:1-19 (DOI:10.1002/clen.201700624)

Tijani JO, Fatoba OO, Madzivire G, Petrik LF (2014) A review of combined advanced oxidation technologies for the removal of organic pollutants from water. Water, Air, Soil \& Pollut. 225(2102):1-30 (DOI: DOI:10.1007/s11270-014-2102-y) 
Tomaszewska M (2007) Industrial wastewater treatment by means of membrane techniques. Polish J Chemical tech. 9(3):138-142

Twesme TM, Tompkins DT, Anderson MA, Root TW (2006) Photocatalytic oxidation of low molecular weight alkanes: observations with $\mathrm{ZrO}_{2}-\mathrm{TiO}_{2}$ supported thin films. Appl. Catal. B: Environ. 64:153-160.

Usman M, Faure P, Hanna K, Abdelmoula M, Ruby C (2012) Application of magnetite catalyzed chemical oxidation (Fenton-like and persulfate) for the remediation of oil hydrocarbon contamination. Fuel 96:270-276

Vaiopoulou E, Melidis P, Aivasidis A (2005) Sulfide removal in wastewater from petrochemical industries by autotrophic denitrification. Water Res. 39(17): 4101-4109

Vargas A, Soto G, Moreno J, Buitron G (2000) Observer-based time-optimal control of an aerobic SBR for chemical and petrochemical wastewater treatment. Water Sci. Technol. 42(5-6): 163- 170

Varjani S, Kumar G, Rene ER (2019) Developments in biochar application for pesticide remediation: Current knowledge and future research directions. J. Environ. Manag. 232:505-513

Varjani SJ (2017a) Microbial degradation of petroleum hydrocarbons. Bioresour Technol 223:277-286

Varjani SJ (2017b) Remediation processes for petroleum oil polluted soil. Indian J Biotechnol 16:157-163

Varjani SJ, Gnansounou E, Pandey A (2017) Comprehensive review on toxicity of persistent organic pollutants from petroleum refinery waste and their degradation by microorganisms, Chemosphere 188:280-291

Varjani SJ, Joshi RR, Kumar PS, Srivastava VK, Kumar V, Banerjee C, Kumar RP (2018) Polycyclic aromatic hydrocarbons from petroleum oil industry activities: Effect on human health and their biodegradation. In: Varjani SJ, Gnansounou, E, Gurunathan, B, Pant D, Zakaria ZA (eds) Waste Bioremediation, Springer Nature, Singapore, pp 185-199

Varjani SJ, Sudha MC (2018) Treatment technologies for emerging organic contaminants removal from wastewater. In: Bhattacharya S, Gupta AB, Gupta A, Pandey A (eds.) Water remediation, Springer Nature, Singapore, pp $91-115$

Varjani SJ, Upasani VN (2017) A new look on factors affecting microbial degradation of petroleum hydrocarbon pollutants. Int. Biodeterior. Biodegrad. 120:71-83

Veyrand B, Sirot V, Durand S, Pollono C, Marchand P, Dervilly-Pinel G, Tard A, Leblanc JC, Le Bizec B (2013) Human dietary exposure to polycyclic aromatic hydrocarbons: results of the second French total diet study. Environ. Int. 54:11-17 
Viggi CC, Presta E, Bellagamba M, Kaciulis S, Balijepalli SK, Zanaroli G, Papini PM, Rossetti S, Aulenta F (2015) The "Oil Spill Snorkel": an innovative bioelectrochemical approach to accelerate hydrocarbons biodegradation in marine sediments. Front Microbiol 6:881: 1-11 (DOI: 10.3389/fmicb.2015.00881)

Vodyanitskii YN, Trofimov SY, Shoba SA (2016) Promising approaches to the purification of soils and groundwater from hydrocarbons (A review). Eurasian Soil Sc. 49:705-713

Ward O, Singh A, Hamme JV (2003) Accelerated biodegradation of petroleum hydrocarbon Waste. J. Ind. Microbiol. Biotechnol. 30:260-270

Xu X, Zhu X (2004) Treatment of refectory oily wastewater by electro-coagulation Process. Chemosphere. 56:889894

Yen CH, Chen KF, Kao CM, Liang SH, Chen TY (2011) Application of persulfate to remediate petroleum hydrocarbon-contaminated soil: feasibility and comparison with common oxidants. J. Hazard. Mater. $186: 2097-2102$

Zafra G, Moreno-Montano A, Absalon A, Cortes-Espinosa D (2015) Degradation of polycyclic aromatic hydrocarbons in soil by a tolerant strain of Trichoderma asperellum. Environ. Sci. Pollut. Res. 22:1034-1042

Zahrim AY, Hilal N (2013) Treatment of highly concentrated dye solution by coagulation/flocculation-sand filtration and nanofiltration. Water Resour. Ind. 3:23-34

Zhang X, He W, Ren L, Stager J, Evans PJ, Logan BE (2015) COD removal characteristics in air-cathode microbial fuel cells. Bioresour Technol. 176:23-31

Zhu Y, Wang D, Jiang L, Jin J (2014) Recent progress in developing advanced membranes for emulsified oil/water separation. NPG Asia Mater. 6:1-11 
498 Table Legend

499 Table 1. Characteristics of oily wastewater/effluents and environmental standards for their discharge

500 Table 2. Petroleum Industry Wastewater Treatment Technologies

501

502

503

504

505

506

507

508

509

510

511

512

513 
Table 1. Characteristics of oily wastewater/effluents and environmental standards for their discharge (Source: G.S.R 186(E), dated 18 $8^{\text {th }}$ March 2008)

\begin{tabular}{clc}
\hline Sr. No. & \multicolumn{1}{c}{ Parameter } & $\begin{array}{c}\text { Limiting value for } \\
\text { concentration* }\end{array}$ \\
\hline 1 & $\mathrm{pH}$ & $6.0-8.5$ \\
2 & Chemical oxygen demand & 125.0 \\
3 & Biological oxygen demand 3 days, $27^{\circ} \mathrm{C}$ & 15.0 \\
4 & Oil and Grease & 5.0 \\
5 & Suspended Solids & 20.0 \\
6 & Total Kjeldahl nitrogen & 40.0 \\
7 & Sulphides & 0.5 \\
8 & Phenols & 0.35 \\
9 & Cyanide & 0.20 \\
10 & Benzene & 0.1 \\
11 & Benzo[a]pyrene & 0.2 \\
12 & Metal contents & \\
& & Hexavalent Chromium
\end{tabular}


$\begin{array}{ll}\text { Lead } & 0.1\end{array}$

$\begin{array}{ll}\text { Mercury } & 0.01\end{array}$

$\begin{array}{ll}\text { Nickel } & 1.0\end{array}$

Zinc $\quad 5.0$

$\begin{array}{ll}\text { Copper } & 1.0\end{array}$

$\begin{array}{ll}\text { Vanadium } & 0.2\end{array}$

*Limiting value for concentration is in $\mathrm{mg} / \mathrm{L}$, except for $\mathrm{pH}$

Table 2. Petroleum industry wastewater treatment technologies (Source: Dimoglo et al. 2004; Lin et al. 2001 2000; Vaiopoulou et al. 2005; Knight et al. 1999

\begin{tabular}{cll}
\hline Sr. No. & Name of the techniques & Treatment details \\
& & \\
\hline 1 & Electrochemical & To remove turbidity, COD, phenol, hydrocarbon and grease by \\
& technologies & using electro coagulation and electro flotation from petroleum \\
& & wastewater \\
\hline 2 & Ozonation and biological & To enhance biodegradation process of bio refractory and the \\
& activated carbon (BAC) & growth of a biofilm have been noticed during laboratory scale pre- \\
& & ozonation and biological activated carbon (BAC) \\
\hline 3 & Anaerobic treatment & Anaerobic digestion method has been used for treatment of \\
& & hydrocarbon pollutants \\
\hline 4 & Aerobic sequencing batch & Observer-based time-optimal control: Control strategy regulates \\
& reactors & and maintains the substrate concentration and feed ratio in the
\end{tabular}




\begin{tabular}{lll}
\hline & reactor. An extended Kalman filter has been used as a nonlinear \\
& observer in a petrochemical wastewater treatment \\
\hline 5 & Autotrophic denitrification & To remove sulfide from petroleum industry waste water, new \\
& alternative treatment for removal of $\mathrm{H}_{2} \mathrm{~S}$ by combination of the \\
& biological method and existing stripping $\mathrm{CO}_{2}$ \\
\hline 7 & Wetlands & Some large-scale project and pilot scale studies have been \\
& conducted for extraction and pumping stations of oil and gas for \\
& treatment using wetland for oil refineries
\end{tabular}

$532 \quad$ Figure Captions

534 Figure 1. Petroleum industry wastewater treatment

535 Figure 2. Treatment of wastewater of petroleum industry: Schematic diagram

536

537

538

539

540

541

542

543

544

545 


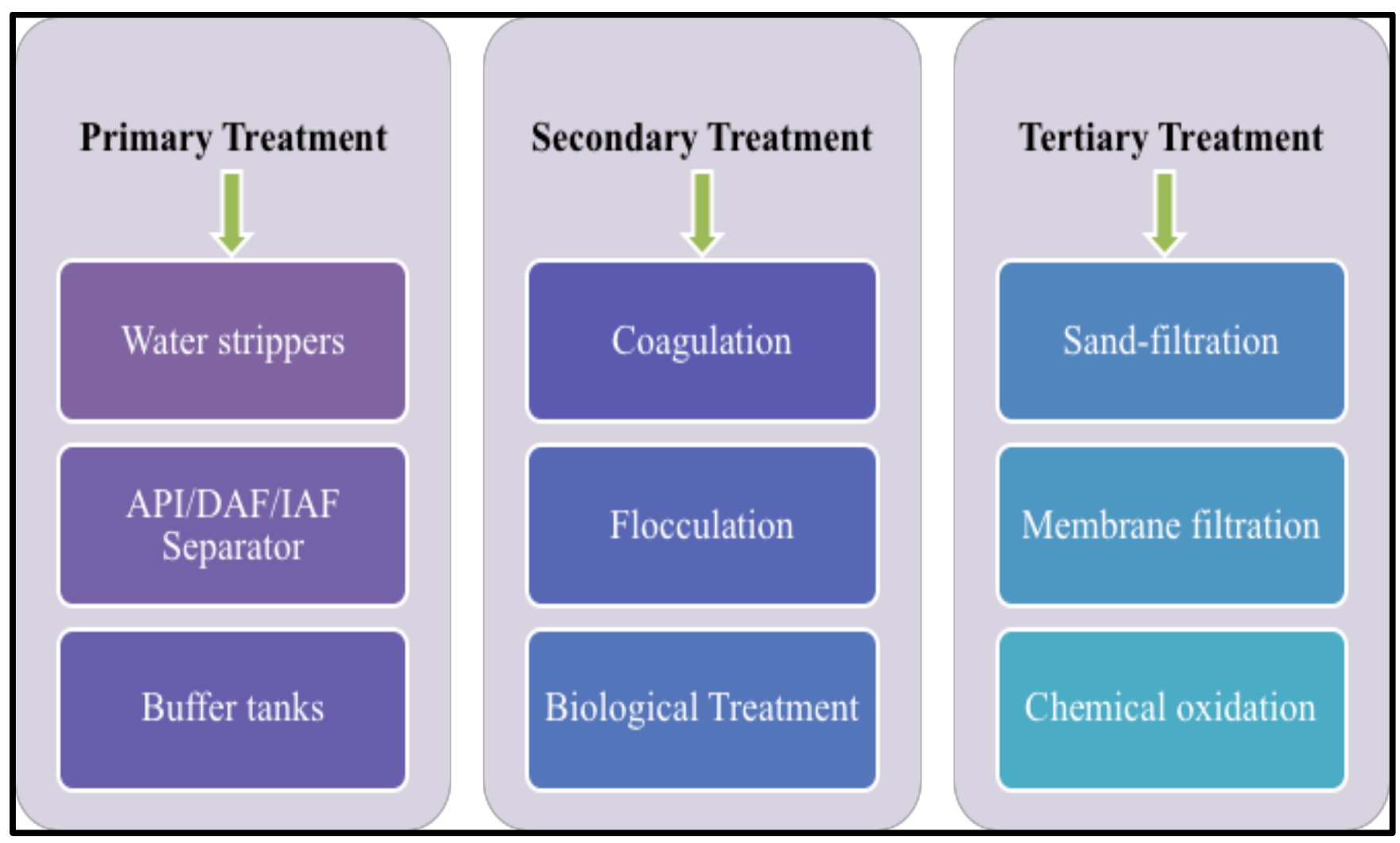




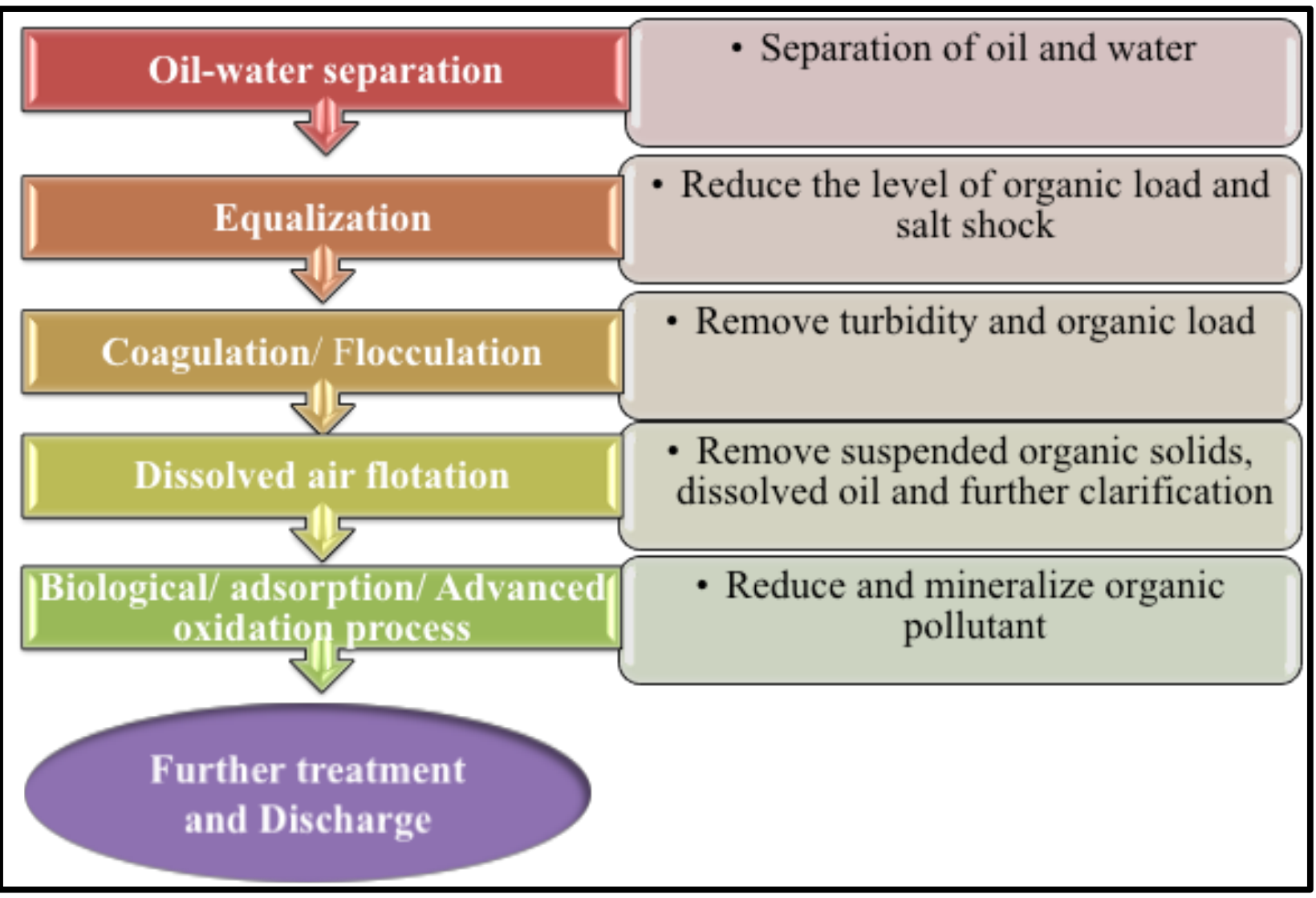

Figure 2. Treatment of wastewater of petroleum industry: Schematic diagram 